\title{
Complexing Capacity of the Nutrient Medium and its Relation to Inhibition of Algal Photosynthesis by Copper
}

\author{
By René Gächter, Ken Lum-Shue-Chan and Y. K. Chau \\ Canada Center for Inland Waters, Burlington, Ontario, Canada \\ Manuscript received 14 February 1974
}

\begin{abstract}
The toxic effect of copper on phytoplankton production is investigated in waters having different complexing capacities. It is demonstrated that a water's complexing capacity does not guarantee that an equivalent amount of copper could be tolerated without adversely affecting algal production. Possible explanations for these findings are offered and discussed.

It is deduced that ionic copper probably is already toxic to planktonic algae at concentrations of about $10^{-10}$ mole/l.
\end{abstract}

\section{Introduction}

Copper sulfate has been used since 1904 to control algal blooms [24]. The concentration recommended for this purpose varies from 20 to about $1,000 \mu \mathrm{g} \mathrm{Cu} / 1[3,9,20$, $21,23,25,26,29,35]$. Compared with the concentration of 1 to $2 \mu \mathrm{g} \mathrm{Cu} / 1$ found by SteEmann Nielsen et al. [31] to be toxic to Chlorella pyrenoidosa and Nitzschia palea, and the findings of CHAU et al. [5], that an addition of only $5 \mu \mathrm{g} / \mathrm{l}$ of copper to Lake Ontario water depressed photosynthesis consistently as much as $50 \%$, these concentrations seem to be rather high.

It has been well documented that the toxicity of copper can be counteracted partially or completely by the addition of strong organic chelators such as NTA $[10,11]$, EDTA [2, 30,31, 32], by extracellular polypeptides of Anabaena cylindrica [12], by a protein digest [31], and by a zooplankton extract [2]. An addition of $\mathrm{FeCl}_{3}$ which in alkaline solution forms negatively charged colloids capable of adsorbing cations or positively charged complexes, also has the same detoxifying effect [32].

From these observations, it was concluded that only the ionic copper species $\left[\mathrm{Cu}\left(\mathrm{H}_{2} \mathrm{O}\right)_{6}\right]^{2+}$ has toxic effects but not its organic chelated species. Such a conclusion is perhaps too exclusive. However, it is reasonable to assume that the free copper ion or its inorganic complexes are more toxic than the organic ones. 
It is assumed that most of the copper in natural waters exists in organic complexed forms and that with a sufficient content of organic ligands, some lake waters have the ability to counteract the toxic effect of further additions of copper [12]. Apart from the possible precipitation of added copper at the usually high $\mathrm{pH}$ conditions in a eutrophic epilimnion, this interaction would then provide an explanation why, for practical control purposes, much higher copper concentrations are needed in some lake waters to diminish or suppress growth of algae than in purely inorganic culture medium. This capability to counteract the toxicity of copper has been attributed to the formation of complexes with natural organic ligands, although the mechanism is not clearly understood [34].

In a recent report, CHAU et al. [7] have described a procedure for the quantitative determination of strong copper binding agents in lake waters. A study was therefore initiated with a two-fold purpose: a) to measure how much ionic copper could be masked by filtered lake waters obtained from different locations, and by aged culture medium in which Chlorella had been grown for several days; b) to relate this masking ability, which might be due to mechanisms such as complexation, colloidal adsorption or even precipitation, to a capacity to buffer further additions of copper without adversely affecting phytoplankton production.

\section{Methods}

\subsection{Measurement of the complexing capacity}

The complexing capacity of a sample is defined as its ability to mask a certain amount of added ionic copper. Since it is not possible at the moment to distinguish between the different masking mechanisms mentioned above, it is assumed in the following discussion that complexation is the most important mechanism.

To measure the complexing capacity, a polarographic method (differential pulse anodic stripping voltammetry), developed by $\mathrm{CHAU}$ et al. [7] was applied, which in principle consists of the following procedure: To aliquots of filtered lake water or culture medium, varying amounts of $\mathrm{Cu}\left(\mathrm{NO}_{3}\right)_{2}$ were spiked. After at least a two-hour equilibration period at $25^{\circ} \mathrm{C}$, the labile $\mathrm{Cu}$ concentration was estimated. Up to a certain level, regardless of the copper spiked, no labile copper could be detected. Above this point the peak current increased linearly with the increasing copper spikes, as shown in Figure 1. The intercept on the abscissa of a plot of peak current in $\mu A$ on the $y$-axis versus the concentration of copper spiked on the $x$-axis represents the complexing capacity of the sample. It is computed from the equation of the least squares regression line of $y$ on $x$ by putting $y=0$.

In this study duplicate measurements were made simultaneously on Princeton Applied Research polarographs (models 170 and 174).

\subsection{Biossay}

The membrane filtered sample $(0.45 \mu)$ was subdivided into $300 \mathrm{ml}$ aliquots which were spiked with increasing amounts of $\mathrm{Cu}\left(\mathrm{NO}_{3}\right)_{2}$. The samples were equilibrated for 2 hours before inoculation of the test algae (Chlorella sp.) or natural phytoplankton collected with a plankton net, mesh size $30 \mu$. This procedure reduced the risk of sudden exposure of the algae to ionic copper not equilibrated with the natural ligands. 
The inoculated samples were then subsequently exposed to light and kept for 24 hours at the approximate temperature of the lake water at the time of collection. The samples were then transferred to $125 \mathrm{ml}$ Pyrex bottles, inoculated with ${ }^{14} \mathrm{C}$ labelled sodium bicarbonate and exposed at the same temperature to $20 \mathrm{Klux}$ in an incubator.

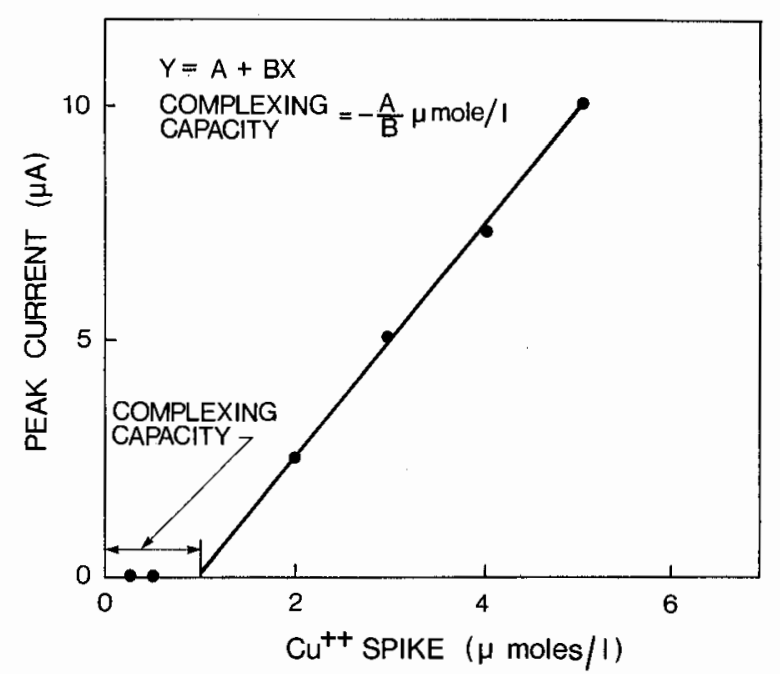

Fig. 1. Diagrammatic representations of complexing capacity.

After a 4-hour exposure the samples were filtered at $180 \mathrm{~mm}$ of mercury through membrane filters (Sartorius SM 11306, $0.45 \mu$; diameter $47 \mathrm{~mm}$ ). To remove adsorbed inorganic ${ }^{14} \mathrm{C}$, the filters were exposed for 20 minutes to fuming $\mathrm{HCl}$. The ${ }^{14} \mathrm{C}$ activity of the filters was assayed using a liquid scintillation counter (Nuclear Chicago Unilux II) as described by LiND and CAMPBELL [19].

\section{Results}

Using the methods described above the following samples were investigated:

1. 10-day old culture of Chlorella with a cell concentration of $8.3 .10^{6} \mathrm{cells} / \mathrm{ml}$. (Composition of the culture medium is listed in Table 1.)

2. 10-day old culture spiked with $1 \mu$ mole EDTA.

3. Water from Hamilton Harbour.

4. Water from the western basin of Lake Ontario.

Table 1. Composition of the nutrient medium.

\begin{tabular}{lrlr}
\hline Compound & $\begin{array}{l}\text { Concentration } \\
\mathrm{mg} / \mathrm{l}\end{array}$ & Compound & $\begin{array}{l}\text { Concentration } \\
\mu \mathrm{g} / \mathrm{l}\end{array}$ \\
\hline $\mathrm{NaNO}_{8}$ & 25.5 & $\mathrm{H}_{3} \mathrm{BO}_{3}$ & 185.5 \\
$\mathrm{~K}_{2} \mathrm{HPO}_{4}$ & 1.0 & $\mathrm{MnCl}_{2}$ & 264.3 \\
$\mathrm{MgCl}_{2}$ & 5.7 & $\mathrm{ZnCl}_{2}$ & 32.7 \\
$\mathrm{MgSO}_{4} \cdot 7 \mathrm{H}_{2} \mathrm{O}$ & 14.7 & $\mathrm{CoCl}_{2}$ & 0.8 \\
$\mathrm{CaCl}_{2} \cdot 2 \mathrm{H}_{2} \mathrm{O}$ & 4.4 & $\mathrm{NaMoO}_{4} \cdot 2 \mathrm{H}_{2} \mathrm{O}$ & 7.3 \\
$\mathrm{NaHCO}_{3}$ & 150.0 & $\mathrm{Fe} \mathrm{EDTA}(1: 1$ complex $)$ & 78.3 \\
\hline
\end{tabular}


5. Water from Niagara River, Ontario.

$\mathrm{pH}$ was maintained at approximately 7 by bubbling $3 \% \mathrm{CO}_{2}$ in air.

The complexing capacity of the samples (Table 2) was obtained from the average of two simultaneous runs.

Table 2. Complexing capacity of the samples expressed as $\mu$ mole $\mathrm{Cu}^{2+} / 1$.

\begin{tabular}{llll}
\hline Sample & \multicolumn{2}{l}{ Complexing capacity } & Average \\
\hline Chlovella culture & 0.69 & 0.66 & 0.67 \\
Chlovella culture $+1 \mu$ mole/l EDTA & estimated & $0.67+1.0$ & 1.67 \\
Water from Hamilton Harbour & 1.28 & 1.18 & 1.23 \\
Water from Lake Ontario & 0.34 & 0.52 & 0.43 \\
Water from Niagara River & 0.44 & 0.43 & 0.44 \\
\hline
\end{tabular}

The effect of various amounts of copper on photosynthesis is shown in Figure 2. It is evident that none of the samples had the capacity to reduce any added ionic copper to a concentration level which was no longer toxic. In every case, an increase of total copper concentration of only $0.1 \mu$ mole $/ 1(6.3 \mu \mathrm{g} / \mathrm{l})$ caused an inhibition of photosynthesis. At the equivalence point where the amount of copper spike is equal

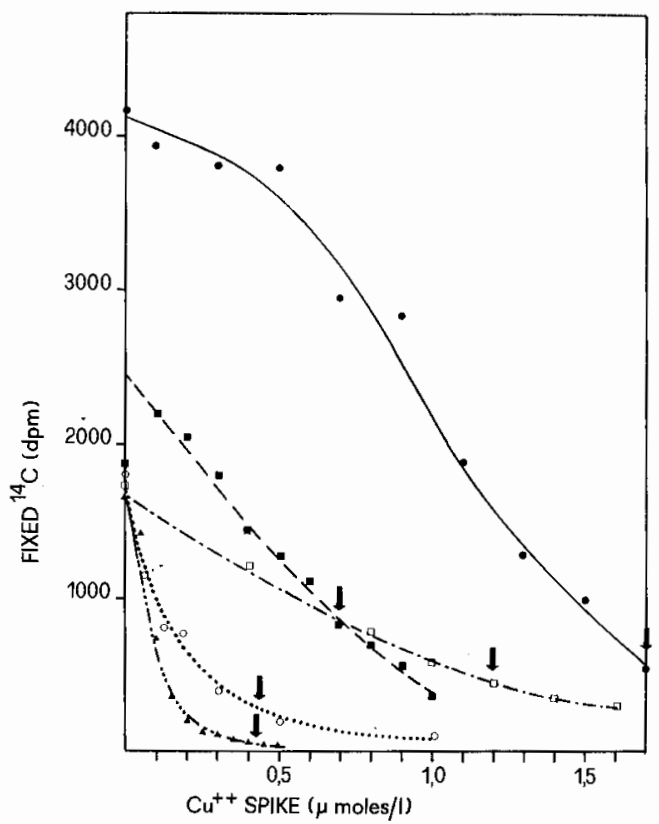

Fig. 2. Suppression of relative algal photosynthesis as a function of the amount of copper spiked. The arrow indicates the sample's complexing capacity.

Chlovella culture medium $+1 \mu$ mole EDTA/1

- - Chlovella culture medium.

$\square-\cdot-\square$ Hamilton Harbour water

o........ O Lake Ontario water

^....... $\Delta$ Niagara river water 
to the complexing capacity of the sample, photosynthesis was already suppressed by 70 to $95 \%$. Thus, a sample's complexing capacity does not guarantee that an equivalent amount of copper could be tolerated by the system without harm.

\section{Discussion}

Copper can exist in fresh water in many soluble forms: As a free copper ion $\left[\mathrm{Cu}\left(\mathrm{H}_{2} \mathrm{O}\right)_{6}\right]^{2+}$, in many inorganic complexes such as $[\mathrm{CuOH}]^{+},\left[\mathrm{Cu}_{2}(\mathrm{OH})_{2}\right]^{2+},[\mathrm{CuHPO}]^{\circ}$, $\left[\mathrm{CuCO}_{3}\right]^{\circ},\left[\mathrm{Cu}\left(\mathrm{CO}_{3}\right)_{2}\right]^{2-},\left[\mathrm{CuSO}_{4}\right]^{\circ}[8]$, in combination with organic complexing agents known to exist in freshwaters such as amino acids, polycarboxylic acids, polypeptides, etc. and adsorbed to inorganic or organic colloids.

In the ocean, total copper concentration varies from about $3 \mu \mathrm{g} / \mathrm{l}$ in the open sea. [14] to about 10 to $90 \mu \mathrm{g} / \mathrm{l}$ in coastal waters depending on location and season $[1,13]$. The general concentration level of copper in most parts of Lake Ontario was in the range of $1-4 \mu \mathrm{g} / \mathrm{l}$. Higher concentrations [10-14 $\mu \mathrm{g} / \mathrm{l}]$ have been found in areas population density and heavy industrialization [5]. In the Sudbury area of Northern Ontario, as high as $46 \mu \mathrm{g} / \mathrm{l}$ of total copper has been observed in some lakes because of mining activity [6]. In two Swiss Lakes (Lake of Lucerne and Greifensee), a concentration of $10 \mu \mathrm{g} / \mathrm{l}$ was estimated [4]. Much higher values were reported by RILEY [27], who found, in three lakes in Connecticut, values of total copper ranging from 9 to $383 \mu \mathrm{g} / \mathrm{l}$. KImBaLL [18] recently estimated $<10$ to $105 \mu \mathrm{g} / \mathrm{l}$ of ionic copper in Knights pond, Massachusetts.

It is generally assumed that most of the copper in natural waters exists in organic complexed forms. However, there is no satisfactory method available at the moment to estimate the percentage of ionic and soluble organic-bound copper in natural waters. The spectrophotometric techniques previously employed $[18,27]$ for the determination of 'ionic' copper used a very powerful complexing agent (diethyldithiocarbamate) which, as demonstrated by KAMP-NIELSEN [17], forms stronger complexes than many naturally occuring ligands. Thus, the determination of the 'ionic' copper concentration by this method might include part or possibly all of the originally complexed copper, and the differentiation between ionic and organic-bound copper is therefore not realistic.

The method presented by Chau and Lum-Shue-Chan [6] for the determination of labile and strongly bound metals in lake water, using differential pulse anodic stripping voltammetry, with acetate to buffer the $\mathrm{pH}$ and to provide constant ionic strength, cannot estimate the concentration of the true ionic species $\left[\mathrm{Cu}\left(\mathrm{H}_{2} \mathrm{O}\right)_{6}\right]^{2+}$ either. The labile metal as determined by this method includes the aquo-complex and acetate exchangeable complexes. However, since these workers very seldom found labile copper in natural waters (detection limit $0.5 \mu \mathrm{g} / \mathrm{l}$ ), it can be concluded that the results obtained by this method are closer to the truth than those obtained by the diethyldithiocarbamate method.

In summary, it is possible to measure total copper at natural concentration levels by different methods, but at the moment there is no method to measure directly ionic copper at concentrations below $10^{-6}$ mole/l. Furthermore, the measurement of labile copper also has its limitations [7]. As long as the total copper concentration is smaller than the total ligand concentration, every result showing labile 
copper concentrations higher than the detection limit $(0.5 \mu \mathrm{g} / \mathrm{l})$ is questionable on account of the dissociation of strong complexes during the three-minute pre-electrolysis time. In addition, the presence of insidious trace organic matter might influence the deposition as well as the stripping step, resulting in broadening shifting and splitting of the copper (-acetate) peak [15].

In the present study, these reservations are not as relevant because in every nutrient medium investigated, the original concentration of labile copper was below the detection limit, and in addition to that, every medium had the ability to mask further additions of ionic copper. Nevertheless, any addition of ionic copper inhibited algal photosynthesis. When we accept as a working hypothesis the general but still unproven assumption, that only the ionic, but not the complexed copper is toxic, and that the masking of added copper was due to complexation, these observations could be explained as follows:

a) the non labile $\mathrm{Cu}$ complexes formed are weak, which implies relatively high ionic copper concentration in equilibrium with them;

b) the ligands present do not have a high specific affinity for copper ions only, which implies cation competition for the ligands;

c) ionic copper is toxic at very low levels.

The observed complexation of copper in natural waters involves the competition of an unknown mixture of ligands with different complexing properties. By comparing copper complexation in Lake Ontario water with known complexing agents such as tartrate $(\log K \sim 5)$, citrate $(\log K \sim 6)$, glycine $(\log K \sim 8)$, NTA (log $K \sim 13$ ), and EDTA $(\log K \sim 19)$, it was found that following the technique outlined above, only those copper complexing agents with a log stability constant greater than ca. 13 could be measured. It was not possible to establish this cut off point accurately since no suitable complexing agent could be found with a $\log \mathrm{K}$ between that for CuNTA and CuEDTA. With CuNTA as an approximate guide, only those complexes with a log conditional constant greater than ca. 10 will be measured (log conditional formation constant for $\mathrm{Cu}$ NTA in $0.04 M$ acetate medium, $\mathrm{pH} 7$, is ca. 9.2). It is obvious, then, that the present method underestimates a sample's total complexing capacity.

Even if it is shown that there are ligands forming relatively strong complexes with copper, this does not mean that they react specifically with copper ions only. Ligands present in natural waters such as amino acids, polypeptides, humic acids, etc., are known to have no large specific affinity for individual metal ions. This unknown degree of competition makes it impossible to establish mathematically any equilibrium model. From the point of view of competition, an increase of every metal concentration would result in a higher concentration of free copper ion and therefore increase the copper toxicity, but on the other hand, different metals might react as antagonists or form colloids capable of adsorbing $\mathrm{Cu}^{2+}$ ions and therefore counteracting the copper toxicity. From this we see, that copper toxicity for a given species depends on the total copper concentration $[\mathrm{Cu}]_{T}$, on the concentration and nature of the different ligands, and also on the distribution and the biological effects of the other metals. At the moment we are able to measure $[\mathrm{Cu}]_{T}$ and a minimum complexing capacity only, but the nature of the ligands involved and consequently the degree of competition of other metals for these ligands are still unknown. 
In such complicated and unknown multiligand-multimetal systems that natural waters are, it is therefore at the moment not only impossible to determine concentrations of ionic copper by means of chemical methods, but also to estimate them by calculation. Thus, it is not possible to relate the inhibition of photosynthesis to an exact absolute concentration of ionic copper. It can only be said for sure that in all of our experiments, a concentration of only $0.5 \mu \mathrm{g} / 1\left(10^{-8}\right.$ mole/l) of labile copper was already heavily toxic. Since 'labile copper' includes all the complexes with a $\log$ conditional formation constant smaller than about 10 , the concentration of ionic copper must have been even much smaller (about $10^{-10}$ mole/l). MANAHAN and SMITH [22] studied the copper requirement of Chlorella and Oocystis and found optimum growth at $1-2 \times 10^{-16} M$ of ionic copper. From this, we might conclude preliminarily, that ionic copper becomes toxic to planktonic algae between $10^{-15}$ and $10^{-10}$ mole/l.

The relationship between complex equilibria and phytoplankton production has been discussed by JoHnston [16], who concluded that the supply of chelating substances was frequently the most crucial aspect of phytoplankton nutrition in seawater. BARBER and RYTHER [2] found that upwelling water rich in nutrients and trace metals showed a relatively low productivity, and that it was possible to increase its production by adding a complexing agent like EDTA or an unspecified zooplankton extract. SteEman NiELSEN et al. [31] suggested that the upwelling water did not contain sufficient organic substances to chelate the heavy metals to remove their toxicity. It can be inferred from the Irving-Williams series that the addition of a chelator will most probably influence the concentration of ionic copper more than that of other divalent transition metal ions. Therefore, the conclusion of SteEmanN NIELSEN et al. [31], that the addition of the chelators removed copper toxicity is reasonable. Figure 2 shows that it was not possible to establish any tolerance range for copper, and also that an addition of $1 \mu$ mole EDTA/1 nearly doubled the photosynthesis of the Chlorella culture. Therefore, also in our experiments, the possibility cannot be excluded that phytoplankton production could have already been controlled by the initial copper concentration.

In addition, STEEMANN Nielsen et al. $[32,33]$ found that Chlorella as well as Nitzschia could counteract the toxicity of copper after some incubation time. They attributed this to either complexation of the copper ions by excretion products or adsorption of copper ions or their complexes to the cell walls. This suggests a possibility for every natural community to counteract the influence of heavy metal toxicity either in a chemical or a physical way. However, their observations could also be interpreted in the following manner. Even a monoculture does not consist of cells which are exactly identical in their physiological behaviour. Rather, every population is a combination of hypersensitive, 'normal', and hyposensitive individuals. As long as the dose of the copper shock is low enough not to kill all cells or to inhibit cell division completely, every population can recover after a lag phase induced by a toxicant, as illustrated in Table 3, where it is assumed that $90 \%$ of the initial population is either growth inhibited or killed. A smaller copper dose would inhibit a lower percentage of the initial population and consequently the lag phase would be shorter.

What is valid for a monoculture will also hold for a natural phytoplankton community composed of more sensitive as well as less sensitive species. It is concei- 
vable therefore, that seasonal changes of total copper concentration as reported by RiLEy [27] and Kimball [18], as well as possible changes in the complexing properties of the waters could influence the phytoplankton succession.

Table 3. Idealized growth of a culture with and without copper addition.

\begin{tabular}{rrrlllll}
\hline Day & \multicolumn{2}{l}{$\begin{array}{l}\text { Growth in the control } \\
\text { no copper added }\end{array}$} & \multicolumn{2}{l}{ Growth after copper addition } \\
& Ind./1 & $\begin{array}{l}\text { \% in- } \\
\text { crease/ } \\
\text { day }\end{array}$ & $\begin{array}{l}\text { Ind./1 } \\
\text { growth inhibited } \\
\text { or dead cells }\end{array}$ & $\begin{array}{l}\text { Ind./1 } \\
\text { cells not } \\
\text { influenced by [Cu] }\end{array}$ & $\begin{array}{l}\text { Ind./1 } \\
\text { total } \\
\text { cells }\end{array}$ & $\begin{array}{l}\text { \% in- } \\
\text { crease/ } \\
\text { day }\end{array}$ \\
\hline 1 & 10,000 & & 9,000 & 1,000 & 10,000 & \\
2 & 20,000 & 100 & 9,000 & 2,000 & 11,000 & 10 \\
3 & 40,000 & 100 & 9,000 & 4,000 & 13,000 & 18 \\
4 & 80,000 & 100 & 9,000 & 8,000 & 17,000 & 31 \\
5 & 160,000 & 100 & 9,000 & 16,000 & 25,000 & 47 \\
6 & 320,000 & 100 & 9,000 & 32,000 & 41,000 & 64 \\
7 & 640,000 & 100 & 9,000 & 64,000 & 73,000 & 78 \\
8 & $1,280,000$ & 100 & 9,000 & 128,000 & 137,000 & 88 \\
9 & $2,560,000$ & 100 & 9,000 & 256,000 & 256,000 & 93 \\
10 & $5,120,000$ & 100 & 9,000 & 512,000 & 521,000 & 97 \\
\hline
\end{tabular}

\section{Summary and conclusions}

1. Natural waters have the property to mask added $\mathrm{Cu}^{2+}$ ions. This capability (the complexing capacity) is attributed to ligands forming copper complexes with $\log$ conditional formation constants greater than or equal to 10 . It is possible to measure this complexing capacity with relatively high accuracy.

2. The complexing capacity of a water sample does not guarantee that the equivalent amount of copper could be tolerated by the system without adversely affecting phytoplankton production.

3. At the present time, it is not possible either to measure the concentration of free copper ions in equilibrium with the ligands or to estimate it indirectly by calculation, since the nature of the ligands and therefore the formation constants with other metals are not known.

4. If only ionic and not complexed copper is toxic, then it is most probable that it inhibits photosynthesis of planktonic algae at concentrations of about $10^{-10}$ mole/1.

5. It is suggested that seasonal variations of the natural copper concentration in concert with the complexing property of the water might have an influence on phytoplankton succession.

This study was carried out at the Canada Center for Inland Waters, Department of the Environment. The senior author gratefully acknowledges a post-doctoral fellowship awarded to him by the N.R.C.C. The authors wish to express their thanks to Professor Werner Stumm and to Dr Mary $\mathrm{E}$. Thompson for encouragement and their critical comments on the manuscript. 


\section{ZUSAMMENFASSUNG}

1. Membranfiltrierte Proben aus naturlichen Gewässern haben die Fähigkeit, zugeführte Kupferionen durch Komplexierung oder kolloidale Adsorption zu maskieren. Es ist möglich, diese Kapazität ("Komplexierungskapazität») polarographisch zu bestimmen. Es werden mit der angewandten Methode jedoch nur Liganden erfasst, die Kupferkomplexe mit einer Komplexbildungskonstanten $K_{f} \gtrsim 10^{10}$ bilden.

2. Es wird gezeigt, dass Kupfer schon toxisch wirkt, lange bevor die so gemessene minimale Komplexierungskapazität der Probe voll ausgeschöpft ist.

3. Bei Gesamtkupferkonzentrationen von weniger als $10^{-6} \mathrm{Mol} / \mathrm{l}$ kann im Moment die Konzentration der mit den unbekannten Liganden oder Kolloiden im Gleichgewicht stehenden freien Kupferionen weder analytisch noch rechnerisch exakt bestimmt werden.

4. Sollte es aber zutreffen, dass nur freie Kupferionen $\left[\mathrm{Cu}\left(\mathrm{H}_{2} \mathrm{O}\right)_{6}\right]^{2+}$ die Photosynthese hemmen, so muss angenommen werden, dass Konzentrationen von weniger als etwa $10^{-10} \mathrm{Mol} / \mathrm{l}$ bereits toxisch wirken.

5. Es ist denkbar, dass saisonale Veränderungen der Kupferkonzentration und der Komplexierungskapazität die jahreszeitliche Sukzession des Phytoplanktons beeinflussen.

\section{RÉSUME}

Les eaux naturelles filtrées sur membrane sont capables de masquer les ions de cuivre par l'adsorption colloïdale ou par formation de complexes. Il est possible de déterminer cette capacité ("complexing capacity") attribuée aux ligands formant des complexes de cuivre d'une constante $K_{f} \gtrsim 10^{10}$ avec une méthode polarographique.

On a démontré que le cuivre est toxique bien avant que cette capacité ne soit épuisée.

Pour l'instant il n'existe ni méthode chimique ni mathémathique pour déterminer la concentration précise du $\left[\mathrm{Cu}\left(\mathrm{H}_{2} \mathrm{O}\right)_{6}\right]^{2+}$.

S'il s'avérait que ce ne sont que les ions libres de cuivre $\left[\mathrm{Cu}\left(\mathrm{H}_{2} \mathrm{O}\right)_{6}\right]^{2+}$ qui inhibent la photosynthèse, il faudrait admettre que des concentrations de $\lesssim 10^{-10} \mathrm{Mol} / 1$ sont déjà toxiques.

Il est bien possible que la variation saisonnière des concentrations du cuivre et de la capacité des eaux de masquer des ion métalliques influence la succession du phytoplaneton.

\section{REFERENCES}

[1] Atkins, W. R. G., The Copper Content of Seawater, J. Mar. Biol. Ass. U.K. 18, 193-198 (1932).

[2] Barber, R.T., and Ryther, J.H., Organic Chelators: Factors Affecting Primary Production in the Cromwell Current Upwelling, J. Exp. Mar. Biol. Ecol. 3, 191-199 (1969).

[3] Bartsh, A.F., Practical Methods for Control of Algae and Water Weeds, Public Health Reports 69, 749-757 (1954).

[4] BURGI, H.R., The Effects of NTA on the Growth of Phytoplankton with Particular Consideration given to Iron as a Microelement, EAWAG News 2 (1973).

[5] Chau, Y.K., Chawla, V.K., Nicholson, H.F., and Vollenweider, R.A., Distribution of Trace Metals and Chorophyll a in Lake Ontario, Proc. 13th Conf. Great Lakes Res., p. 659-672 (1970).

[6] CHAU, Y.K., and LUM-ShuE-ChAN, K., The Determination of Labile and Strongly Bound Metais in Lake Watev, Water Res., in press (1974).

[7] Chau, Y. K., Gächter, R., and Lum-Shue-Chan, K., The Determination of the Complexing Capacity of Lake Waters, Submitted to J. Fish. Res. Bd. Can. (1974).

[8] Childs, C.W., Chemical Equilibrium Models in Lake Water, Proc. 14th Conf. Great Lakes Res., p. 198-210 (1971).

[9] Domogalla, B., Eleven Years of Chemical Treatment of the Madison Lakes. Its Effect on Fish Foods, Trans. Am. Fish Soc. 65, 115-120 (1935).

[10] ErICkson, S.J., Lackie, N., and Maloney, T.E., A Screening Technique for Estimating Copper Toxicity to Estuarine Phytoplanikton, J. Water Poll. Contr. Fed. 42, R 270-278 (1970a).

[11] ERIckson, S.J., MaLONEY, T.E., and Gentile, H.H., Effect of Nitrilotriacetic Acid on the Growth and Metabolism of Estuarine Phytoplankton, J. Water Poll. Contr. Fed. 42, R 229-235 (1970b). 
[12] Fogg, G.E., and Westlake, D.F., The Importance of Extra-Cellular Products of Algae in Fresh Water, Int. Assoc. Theoret. Appl. Limnol. 12, 219-232 (1955).

[13] Galtsoff, P. S.E., Copper Content of Seawater, Ecology 24, 236-264 (1943).

[14] GoldgerG, E.D., The Oceans as a Chemical System, in: The Sea, Vol. 2 (Ed. M.N. Mill; Wiley Interscience 1963), p. 3-25.

[15] Hume, D.N., and CARTER, J.N., Characteristics of the Mercury Coated Graphite Electrode in Anodic Stripping Voltammetry: Application to the Study of Trace Metals in Environmental Water Systems, Chemia Analityczna 17, 747-759 (1972).

[16] Johnsten, R, Seaseater, the Natural Medium of Phytoplankton. Part II. Trace Metals and Chelation, and General Discussion, J. Mar. Biol. Ass. U.K. 44, 87-109 (1964).

[17] Kamp-Nielsen, L., Some Comments on the Determination of Copper Fractions in Natural Waters, Deep-Sea Res. 19, 899-902 (1972).

[18] Kimball, K.D., Seasonal Fluctuations of Ionic Copper in Knights Pond, Massachusetts, Limnol. Oceanogr. 18, 169-172 (1973).

[19] LIND, O.T., and CAMPELL, R.S., Comments on the Use of Liquid Scintillation for Routine Determination of ${ }^{14} \mathrm{C}$ Activity in Production Studies, Limnol. Oceanogr. 14, 787-789 (1969).

[20] Mackenthun, K.M., The Chemical Control of Aquatic Nuisances, Committee on Water Pollution, Madison, Wisconsin (1959).

[21] Maloney, T.E., and Palmer, C., Toxicity of Six Chemical Compounds in Thivty Cultures of Algea, Water Sewage Works 103, 509-513 (1956).

[22] Manafan, S.E., and Smith, M.J., Copper Micronutrient Requirement for Algae, Environ. Sci. Techn. 7, 829-833 (1973).

[23] Mandelli, E.F., The Inhibitory Effects of Copper on Marine Phytoplankton, Contrib. Mar. Sci. 14, 47-57 (1969).

[24] Moore, G.T., and Kellerman, K.F., Copper as an Algicide and Disinfectant in Water Supplies, U.S. Dept. Agric. Bur. Plant Industry, Buil. No. 76, 5-55 (1905).

[25] Palmer, C.M., and Maloney, T.E., Preliminary Screening for Potential Algicides, Ohio J. Sci. 55, 1-8 (1955).

[26] Prescotr, G.W., Objectionable Algae with Reference to the Killing of Fish and Other Animals, Hydrobiologia 1, 1-13 (1948).

[27] RILEy, G.A., Limnological Studies in Connecticut, Ecol. Monogr. 9, 53-94 (1939).

[28] Ringвom, A., Complexation in Analytical Chemistry (Wiley Interscience, New York 1963).

[29] RoDHE, W., Die Bekämpfung einer Wasserblitte von Microcystis und die gleichzeitige Förderung einer neuen Hochproduktion von Pediastrum im See Noorvikon bei Stockholm, Verh. Internat. Ver. Limnol. 10, 372-376 (1949).

[30] Soeder, D.J., Schulze, G., and ThIele, D., Einfluss verschiedener Kulturbedingungen awf das Wachstum in Synchronkulturen von Chlovella fusca Sh. et $K \boldsymbol{r}$., Arch. Hydrobiol. Suppl. 33, 127-171 (1967).

[31] Steemann Nielsen, E., and Wium-Andersen, S., Copper Ions as Poison in the Sea and in Freshwater, Mar. Biol. 6, 93-97 (1970a).

[32] Stemmann Nielsen, E., and Kamp-Nielsen, L., Influence of Deleterious Concentrations of Copper on the Growth of Chlorella pyrenoidosa, Physiol. Plant. 23, 828-840 (1970b).

[33] Steemann Nielsen, E., and Wium-Andersen, S., The influence of Copper on Photosynthesis of Growth in Dialoms, Physiol. Plant. 24, 480-484 (1971).

[34] Stumm, W., Die Rolle der Komplexbildung in natïrlichen Gewässern und allfällige Beziehungen zur Eutrophievung, Gewässerschutz-Wasser-Abwasser 8, 57-87 (1972).

[35] Vaulina, Z.N., The Effect of Copper on Soil Algae, Bot. Zhur. 42, 1097-1099 (1957).

Senior author's address:

Dr. René Gächter, Hydrobiologisches Laboratorium ETH, CH-6047 Kastanienbaum, Switzerland. 